\title{
Framing Pemberitaan SKH Kompas Terhadap Boediono Terkait Kasus Bailout Bank Century
}

\author{
Niko \\ Program Studi Ilmu Komunikasi Fakultas Ilmu Sosial Ilmu Politik \\ Universitas Pembangunan Nasional "Veteran" Yogyakarta \\ Jalan Babarsari No.2 Tambakbayan Yogyakarta 55281 \\ Telp : 085747803904/email: nikosaja_33@yahoo.co.id
}

\begin{abstract}
The major problem in this research is to know how SKH Kompas indicate their attitudes regarding media coverage framing analysis SKH Kompas Boediono related case against Bailout Century Bank (Edition January-March 2010). Boediono was chosen because in that case he that has authority in the disbursement of Century Bank, which at the time was serving as Governor of Indonesian Bank. This study uses Framing Analysis Research Methods (Framing Analysis) developed by Zhongdang Pan and Gerald M. Kosicki. This framing analysis model used to explain how to compile the facts (syntax), how the facts narrated (the script) and written (thematic), then how the facts are given emphasis (rhetorical). Based on the results of research conducted, Frame of SKH Kompas has a tendency to urge the government to solve completely the case of the Century, without any political intervention in it as well as other matters that can only make this case dragged on without any resolution. And in a related case reported figure Boediono Century Bank, SKH Kompas has a tendency to abstain from doing any news or make news attack Boediono which makes as if Boediono not guilty. The trend was more directed to settle the case desakkan Century by the Government. Granting and suppression as well as protrusion of the events on the news Boediono figure related to the case of Century Bank Bailout, ways and techniques that are performed by the SKH Kompas is to do a selection of words used in preparing the report text as a whole. It will make informed news audiences will easily digestible and easy to understand or be understood so that audiences will be affected by the attitudes of SKH Kompas on an issue. Keywords: Analysis Framing; Century Bank; Boediono
\end{abstract}

\begin{abstract}
Abstrak
Masalah utama dalam penelitian ini adalah untuk mengetahui bagaimana SKH Kompas menunjukkan sikap mereka dengan melakukan framing liputan media SKH Kompas Boediono terkait kasus terhadap Bailout Century Bank (Edisi Januari-Maret 2010). Boediono dipilih karena dalam hal ini ia yang memiliki kewenangan dalam pencairan Bank Century, yang pada saat itu menjabat sebagai Gubernur Bank Indonesia. Penelitian ini menggunakan Framing Analysis Research Methods (Framing Analysis) yang dikembangkan oleh Zhongdang Pan dan Gerald M. Kosicki. Model analisis framing ini digunakan untuk menjelaskan bagaimana menyusun fakta (sintaks), bagaimana fakta-fakta yang diriwayatkan (naskah) dan tertulis (tematik), lalu bagaimana fakta-fakta diberikan penekanan (retoris). Berdasarkan hasil penelitian yang dilakukan, Kerangka SKH Kompas memiliki kecenderungan untuk mendesak pemerintah untuk menyelesaikan sepenuhnya kasus Century, tanpa intervensi politik di dalamnya serta hal-hal lain yang hanya dapat membuat kasus ini terseret tanpa penyelesaian apapun. Dan dalam kasus terkait yang dilaporkan sosok Boediono Bank Century, SKH Kompas memiliki kecenderungan untuk tidak melakukan berita apapun atau membuat berita menyerang Boediono yang membuat seolah-olah Boediono tidak bersalah. Tren ini lebih diarahkan untuk menyelesaikan kasus Desakkan Century oleh Pemerintah. Pengabulan dan penekanan serta penonjolan peristiwa pada berita Boediono selaku tokoh terkait dengan kasus Bailout Bank Century, cara dan teknik yang dilakukan oleh SKH Kompas adalah melakukan pemilihan kata-kata yang digunakan dalam menyiapkan teks laporan secara keseluruhan. Hal ini akan membuat berita dicerna lebih mudah oleh audiens dan mudah dimengerti atau dipahami sehingga audiens akan terpengaruh oleh sikap SKH Kompas pada sebuah isu. Kata kunci: Analisis framing; Bank Century; Boediono
\end{abstract}




\section{Pendahuluan}

Topik mengenai Kasus Bailout Bank Century beberapa waktu kemarin sangat hangat di bicarakan oleh masyarakat Indonesia, kasus ini menyingkirkan beberapa kasus yang santer dibicarakan oleh media sebelumnya yang terjadi bersamaan dengan munculnya berita ini, seperti kasus Prita dengan RS Omni Internasional, Berita tentang hasil pemilu, dan program 100 hari SBY seolah terlupakan begitu saja. Hal ini tidak lepas dari peran media yang sangat gencar memberitakan mengenai kasus Century ini hampir setiap hari. Sejak Isu Bailout ini mengemuka, hampir semua media massa di Indonesia menjadikan Kasus ini materi berita utama

Dalam kasus tersebut terselip seorang tokoh sentral yang memiliki wewenang dalam pengucuran dana Bank Century tersebut, yaitu Mantan Gubernur Bank Indonesia yang sekarang menjabat sebagai Wakil Presiden yaitu Prof. Dr. Boediono. Tokoh ini hampir setiap saat di bicarakan semenjak kasus Bailout Bank Century muncul ke permukaan dari media online, media elektronik maupun media Cetak, walaupun masih ada beberapa tokoh lain yang juga dikaitkan dalam pengucuran bantuan dana talangan tersebut. Perbedaan ideologi dalam suatu media membuat penyajian berita terhadap seorang tokoh juga menjadi berbeda, ada yang cenderung menyudutkan Boediono, justru ada pula sebaliknya yang dalam penyajiannya bersikap pro terhadap tokoh tersebut. Walaupun juga kadang ditemukan beberapa media yang netral dalam menyajikan pemberitaan mereka berdua. Wajar jika kasus ini menjadi laporan utama media, karena didalamnya terkandung unsur politik dan ekonomi yang merupakan konsumsi headline dari media massa hampir setiap harinya.

Kasus Bailout Bank Century merupakan suatu proses yang panjang dan bertahap-tahap, bahkan dari awal kasus ini muncul hingga penelitian ini dilakukan proses penyelesaian ini belum menemui titik akhir. Dari sekian banyak tahap tersebut, tahap yang pemanggilan Boediono sebagai saksi untuk dimintai keterangan oleh pansus terkait pemberian dana talangan tersebut menarik untuk dilihat.
Pansus Century pada awalnya memanggil beberapa saksi dari jajaran dewan gubernur BI untuk dimintai keterangan terkait merger tiga bank yang menjadi awal Bank Century terjadi, diantaranya Burhanuddin Abdullah, Miranda Goeltom, Anwar Nasution, Aulia Pohan. Kemudian berkembang menjadi pemanggilan beberapa deputi Gubernur BI yang merupakan penggambil otoritas kebijakan tertinggi pemberian dana talangan (bailout) Bank Century, dan Boediono pun masuk kedalam deretan saksi yang akan dimintai keterangan oleh pansus. Boediono yang menjabat Wakil Presiden menerima panggilan tersebut.

Pemanggilan beberapa saksi tersebut merupakan rekomendasi Pansus Century, untuk menjamin optimalisasi kerja pansus dalam mendapatkan data. Penonaktifan kedua pejabat yang bersifat sementara itu untuk menjamin akuntabilitas dan moralitas yang bersangkutan, ketiga adalah untuk merespons suasana kebatinan masyarakat yang meminta keduanya mundur.

Pemanggilan terhadap Boediono dilakukan sebanyak dua kali yang pertama adalah pada 22 Desember 2009 dan yang kedua adalah pada 12 Januari 2010. Dua kali pemanggilan dilakukan karena pada pemberian keterangan pertama tema kurang mendalam dan masih banyak hal yang belum jelas terkait pemberian dana talangan (bailout), sehingga pansus melakukan pemanggilan yang kedua.

Di dalam setiap penyajian berita tersebut terdapat pesan yang hendak di sampaikan oleh media terhadap khalayak, pesan ini mewakili dan merupakan representasi dari suatu ideologi yang dianut oleh media tersebut. Ideologi masingmasing media tersebut merupakan dasar dalam kebijakan redaksional media tersebut yang dapat dilihat dari penyajian pemberitaan media itu. Ideologi tersebut ingin disampaikan kepada khalayak sehingga ideologi tersebut sangat mempengaruhi pola pikir dan perspektif khalayak, media cetak memiliki kemampuan untuk itu. 
Banyak hal yang dapat mempengaruhi ideologi dari suatu media, bisa berasal dari siapa pemilik dana pada perusahaan media itu, dapat pula berasal dari siapa pendiri media tersebut, dan juga segmentasi khalayak dapat mempengaruhi ideologi tersebut. Proses produksi berita dalam penyajiannya akan membentuk sebuah frame yang mana hal ini berasal dari ideologi tersebut. Oleh karena itu secara tidak sadar khalayak yang menjadi konsumen media secara tidak langsung digiring kedalam frame yang di buat oleh media tersebut.

Media menentukan mana yang merupakan berita penting dan berita yang dianggap tidak perlu, dan juga media menentukan mana peristiwa yang dianggap penting dan dijadikan headline dan mana berita yang di anggap biasa, dari sinilah frame itu muncul. Perlahan-lahan khalayak ikut terbawa oleh frame tersebut, khalayak pun mampu menilai bahwa apa yang disajikan dalam headline merupakan hal yang penting dan apa yang terselip di bagian dalam koran dan kolom-kolom kecil merupakan berita biasa dan itu tidak di anggap penting oleh khalayak.

Dalam penyajian suatu berita, media memiliki frame yang berbeda demikian pula wartawan yang merupakan garda terdepan dan ujung tombak dari suatu pencarian berita juga memiliki frame yang berbeda pula. Oleh karena itu dapat pula dikatakan bahwa frame yang terbentuk dari suatu berita merupakan hasil dari seleksi frame dari orangorang yang terdapat di dalam produksi media.

Dalam pemberitaannya suatu media harus benar-benar merefleksikan kepentingan publik. Namun permasalahan terkadang muncul dari suatu media, dimana dalam penyajian dan pembentukan frame, media tersebut terdapat memiliki tujuantujuan tertentu yang terselubung dan hal ini berakibat pada apa yang disajikan oleh media, bukanlah merupakan realita yang sebenarnya, dan hal ini tidak dapat dipahami oleh khalayak umum.

Hal ini yang menjadi masalah, apa yang dibentuk dalam pemberitaan tersebut menghasilkan pola pemikiran yang merupakan representasi dari kepentingan terselubung tersebut sehingga berakibat terbentuknya suatu khalayak yang memiliki pola pemikiran yang sama dengan unsur kepentingan terselubung tersebut. Itulah yang menyebabkan banyak orang melakukan penelitian terhadap isi media, hal ini merupakan suatu kontrol terhadap media yang melaksanakan tugasnya tidak sesuai dengan fungsinya. Dengan penelitian tersebut peneliti dapat melihat bagaimana suatu berita dapat menunjukan sikap dari institusi media tersebut.

\section{Metode Penelitian}

Jenis penelitian yang dipakai dalam penelitian ini adalah penelitian kualitatif yang bersifat deskriptif analisis untuk melihat kecenderungan surat kabar dalam mengkonstruksi dan menulis berita khususnya terkait pemberitaan SKH Kompas terhadap Boediono dalam Kasus Bailout Bank Century dengan menggunakan analisis framing. Dalam analisis framing yang kita lihat adalah bagaimana cara media memaknai, dan membingkai kasus atau peristiwa yang diberitakan. Metode semacam ini tentu saja mencoba mengerti, dan menafsirkan makna dari suatu teks dengan jalan menguraikan bagaimana media membingkai isu. Peristiwa yang sama bisa jadi dibingkai secara berbeda oleh media.

Sebagai sebuah metode analisis teks, analisis framing mempunyai karakteristik yang berbeda dibanding dengan analisis isi kuantitatif. Dalam analisi isi kuantitatif yang ditekankan adalah isi (content) dari suatu pesan atau teks komunikasi. Sementara dalam analisis framing, yang menjadi pusat perhatian adalah pembingkaian pesan dari teks (Eriyanto,2005:9-10)

Dalam pandangan ilmu komunikasi, analisis framing dipakai untuk membedah cara-cara atau ideologi media saat mengkonstruksikan fakta. Analsis ini mencermati strategi seleksi, penonjolan dan pertautan fakta kedalam berita agar lebih bermakna, lebih menarik, lebih berarti atau lebih diingat untuk menggiring interpretasi khalayak sesuai dengan perspektifnya. 
Dengan kata lain analisis framing berusaha untuk mengetahui bagaimana perspektif atau cara pandang yang digunakan wartwan ketika menyeleksi isu dan menulis berita. Ada dua esensi utama dari framing, Pertama. Bagaimana peristiwa dimaknai, hal ini berkaitan dengan bagian mana yang diliput dan mana yang tidak diliput. Kedua, bagaimana fakta itu ditulis. Aspek ini berhubungan dengan pemakaian kata, kalimat dan gambar untuk mendukung gagasan.

Surat kabar dalam melakukan penonjolan pada suatu peristiwa harus cermat agar dapat mengena dengan tepat. Framing bukan mempertanyakan apa yang diberitakan surat kabar dalam suatu peristiwa, melainkan bagaimana suatu peristiwa tersebut dibingkai, mana yang ditonjolkan dan mana yang dilupakan.

Obyek dalam penelitian ini adalah beritaberita yang terdapat dalam SKH Kompas mengenai Kasus Bailout Bank Century yang dimana didalamnya membahas tentang Boediono edisi Januari-Maret 2010. Waktu tersebut dipilih karena pada saat itu Kasus Bailout Century mulai mencuat dan memasuki tahap proses pemanggilan Boediono sebagai saksi di depan Panitia Pansus Century. Pemilihan SKH Kompas sebagai bahan penelitian dikarenakan SKH tersebut merupakan SKH berkualitas dan beredar secara nasional dan memiliki segmen pembaca jelas dan jumlah pembaca yang besar, sehingga diharapkan hasil yang diperoleh dapat mewakili gambaran nyata media massa secara nasional

Adapun berita yang berhubungan dengan topik ini yaitu, 1. "BOEDIONO: CENTURY DIRAMPOK Pansus Bank Century Mencecar". Bersumber dari Kompas 13 Januari2010;2. "Bank Century WAPRES INGATKAN CARA YANG ELEGAN". Bersumber dari Kompas 30 Januari 2010; 3. "Hak Angket Bank Century BOEDIONO: ITU BARU PANDANGAN POLITIK". Bersumber dari Kompas 25 February 2010; 4. "BOEDIONO: INI RISIKO HIDUP Pansus Century Masih Alot Membahas Kesimpulan". Bersumber dari Kompas 27 February 2010; 5.
"Hak Angket WAPRES BOEDIONO BIASABIASA SAJA". Bersumber dari Kompas 4 Maret 2010; 6. "HINDARI INTERVENSI POLITIK Boediono Tegaskan Pantang Mundur". Bersumber dari Kompas 6 Maret 2010;

Dalam penggumpulan data, peneliti menggunakan buku-buku literatur yang relevan dan berkaitan dengan masalah dalam penelitian ini. Studi dokumentasi ini dilakukan untuk mendapatkan data-data dan materi penelitian yang berkaitan dengan sajian berita tentang Kasus Bailout Bank Century yang didalamnnya terdapat sosok Boediono yang disebut-sebut terlibat. Data yang terkumpul kemudian akan dimasukkan dalam kategori yang telah ditentukan untuk memperkaya penelitian ini.

Dalam mengumpulkan data penelitian, peneliti menggunakan analisis teks. Analisis teks disini adalah ketika peneliti menganalisis teks berita yang ditulis oleh Surat Kabar Harian Kompas, adapun yang dianalisis peneliti adalah judul, lead, latar informasi, pernyataan sumber, penutup, kelengkapan unsur berita (what, when, where, why, who, dan how) dan juga pemilihan kata yang dipakai dalam berita.

Untuk menganalisis teks berita pada SKH Kompas, peneliti menggunakan model framing dari Zhondang Pan dan Gerald M. Kosicki. Model tersebut dipilih peneliti karena model ini merupakan salah satu model yang paling populer dan banyak dipakai oleh peneliti. Bagi Pan dan Kosicki (Eriyanto, 2002: 251), analisis framing ini dapat menjadi salah satu alternatif dalam menganalisis teks media di samping analisis isi kuantitatif. Analisis framing dilihat sebagaimana wacana publik tentang suatu isu atau kebijakan dikonstruksi dan dinegosiasikan. Model yang diperkenalkan oleh Pan dan Kosicki ini tidak dapat dilepaskan dari konteks sosial politik Amerika.

Perangkat framing dapat dibagi ke dalam empat struktur besar. Pertama, struktur sintaksis. Sintaksis berhubungan dengan bagaimana wartawan menyusun peristiwa, pernyataan, opini, kutipan, pengamatan atas peristiwa ke 
dalam bentuk susunan umum berita. Dengan demikian dalam struktur ini dapat diamati dari bagan berita (lead yang dipakai, latar, headline, kutipan yang diambil, dan sebagainya). Intinya, peneliti mengamati bagaimana wartawan memahami peristiwa yang dapat dilihat dari cara ia menyusun fakta ke dalam bentuk umum berita. Kedua, struktur skrip. Skrip berhubungan dengan bagaimana wartawan mengisahkan atau menceritakan peristiwa ke dalam bentuk berita. Struktur ini melihat bagaimana strategi cara bercerita atau bertutur yang dipakai oleh wartawan dalam mengemas peristiwa ke dalam bentuk berita. Ketiga, struktur tematik. Tematik berhubungan dengan bagaimana wartawan mengungkapkan pandangannya atas peristiwa ke dalam proposisi, kalimat atau hubungan antar kalimat yang membentuk teks secara keseluruhan. Struktur ini akan melihat bagaimana pemahaman itu diwujudkan dalam bentuk yang lebih kecil. Keempat, struktur retoris. Retoris berhubungan dengan bagaimana wartawan menekankan arti tertentu ke dalam berita. Struktur ini akan melihat bagaimana wartawan memakai pilihan kata, idiom, grafik, dan gambar yang dipakai bukan hanya mendukung tulisan, melainkan juga menekankan arti tertentu kepada pembaca.

Analisis framing merupakan salah satu metode analisis teks yang berada dalam kategori penelitian konstruksionis. Konsentrasi penelitian pada paradigma konstruksionis adalah menemukan bagaimana peristiwa atau realitas tersebut dikonstruksi dalam sebuah bentuk berita. Konstruksionis lebih melihat komunikasi sebagai produksi dan pertukaran makna. Analisis data disajikan secara kualitatif dari seluruh objek penelitian, dilihat dari struktur sintaksis, skrip, tematik, dan retoris.

Teknik pemeriksaan keabsahan data digunakan untuk mengetahui keakuratan data penelitian dan hasil penelitian secara keseluruhan sehingga penelitian dapat dipertanggung jawabkan. Penelitian bersifat kualitatif yaitu bagaimana isi pemberitaan dalam surat kabar dipandang dari segi analisis framing.
Triangulasi merupakan cara paling umum digunakan untuk peningkatan keakuratan data dalam penelitian kualitatif. Dan terbagi ke dalam empat macam teknik triangulasi, yaitu (1) triangulasi sumber, (2) trianggulasi peneliti, (3) triangulasi metode dan (4) trianggulasi teori

Teknik triangulasi yang dipakai atau digunakan oleh peneliti adalah triangulasi sumber. Dalam triangulasi ini, peneliti wajib menggunakan beragam sumber yang ada dalam mengumpulkan data. Peneliti membandingkan hasil penelitian dengan dokumen atau pustaka yang berkaitan dengan penelitian. Dokumen atau pustaka yang digunakan peneliti adalah buku yang berisi tentang kebijakan redaksional Surat Kabar Harian Kompas dalam menulis berita dan juga visi dan misi Surat Kabar Harian Kompas. Adanya buku tersebut dapat membantu untuk mengetahui apakah hasil penelitian mengenai pandangan dan cara Surat Kabar Harian Kompas dalam membingkai berita terkait pemberitaan terhadap Boediono terkait kasus Bailout Bank Century.

\section{Hasil Penelitian dan Pembahasan}

Dalammemberitakan tentang sosok Boediono dalam kasus Bailout Bank Century, pers memiliki peran yang sangat penting. Dengan adanya peran yang diperoleh pers tersebut, diharapkan akan terlihat kebenaran yang sesungguhnya dari suatu keputusan kebijakkan pemberian dana talangan kepada Bank Century yang pada saat itu berada dalam keadaan krisis. Berita yang diinformasikan oleh pers kepada khalayak sering kali dapat mempengaruhi pandangan dan sikap khalayak.

Berita yang disajikan dalam suatu media itu tidak apa adanya. Hal itu karena peristiwa atau fakta yang akan dijadikan berita dan disajikan kepada khalayak harus melalui proses kronstruksi terlebih dahulu agar berita tersebut menjadi layak untuk diinformasikan kepada khalayak. Konstruksi itu sendiri dilakukan dengan pemilihan penggunaan gaya bahasa yang digunakan dalam menulis berita dan disesuaikan dengan pandangan media massa pada peristiwa yang terjadi. Semua 
itu dilakukan agar dapat mempengaruhi sikap dan pandangan pembaca. Konstruksi itu juga yang membedakan isi berita diantara media yang satu dengan media lainnya. Dalam memberitakan suatu peristiwa, media massa sering kali mengalami kendala. Kendala itu karena adanya perbedaan kepentingan dalam diri media maupun dari luar lingkungan media. Dari dalam media seringkali dipengaruhi oleh ideologi yang dipakai atau dianut media yang bersangkutan. Untuk yang berasal dari luar media seperti sumber iklan dan pihak atau individu yang mempunyai kaitan dengan berita yang akan diinformasikan kepada khalayak. Semua itu menunjukkan bahwa media tidak bisa hidup sendiri.

Kasus Bank Century ini dimulai pada sekitar bulan Oktober tahun 2008 lalu. Diawali dengan jatuh temponya sekitar US\$ 56 juta surat-surat berharga milik Bank Century dan akhirnya gagal bayar. Bank Century pun menderita kesulitan likuiditas. Akhir Oktober 2008itu,CARataurasiokecukupanmodalBank Century minus 3,53\%. Kesulitan likuiditas tersebut berlanjut pada gagalnya kliring atau tidak dapat membayar dana permintaan nasabah oleh Bank Century yang diakibatkan oleh kegagalan menyediakan dana (prefund) sehingga terjadi rush. BI yang pada saat itu dipimpin oleh Boediono lalu mengadakan rapat konsultasi dengan Menteri Keuangan (Menkeu) Sri Mulyani yang sedang berada di Amerika Serikat melalui teleconference.

Pada 20 November 2008, BI mengirimkan surat kepada Menkeu, yang berisikan pemberitahuan penetapan Bank Century sebagai bank gagal berdampak sistemik dan memerlukan penanganan lebih lanjut. BI kemudian mengusulkan dilakukannya langkah penyelamatan oleh Lembaga Penjamin Simpanan (LPS). Pada 23 November 2008, LPS memutuskan untuk memberikan dana talangan sejumlah Rp. 2,7 Triliun untuk meningkatkan CAR menjadi
10\%. 3 LPS kemudian juga memberikan dana sebesar Rp. 2,2 $\mathrm{T}$ untuk memenuhi tingkat kesehatan Bank Century pada awal Desember. Awal Desember itulah, ribuan investor Antaboga mulai mengajukan tuntutan terhadap penggelapan dana investasi senilai Rp. 1,38 T yang ditengarai mengalir kepada Robert Tantular.

Pemberitaan media massa pada masalah Bailout Bank Century sudah dilakukan oleh Surat Kabar Harian Kompas, terutama sosok Boediono yang dinilai memiliki tanggung jawab yang besar terhadap keputusan pemberian dana talangan tersebut.

Pada headline berita pertama yakni "Boediono : Bank Century Dirampok" dapat dilihat, bagaimana Kompas ingin menggambarkan bahwa kejadian yang dialami oleh Bank Century bukan karena kesalahan pengambilan kebijakan dalam hal ini Boediono melainkan karena Dirampok. Dalam headline yang ditulis, Kompas juga melakukan konstruksi realitas media, Konstruksi tersebut terlihat pada pemilihan kata untuk menulis headline. Dalam headline tersebut, Kompas menggunakan kata "Dirampok" untuk menggambarkan penyebab Bank Century mengalami krisis pada saat itu sehingga kebijakan Bailout harus diambil pemerintah. Kompas menggunakan kata "dirampok" yang merupakan penekanan dari sekedar kata pencurian, dimana dirampok merupakan tindakkan sengaja yang dilakukan seseorang untuk mengambil sesuatu yang bukan miliknya, dan hal tersbut menurut Boediono dilakukan oleh pemilik Bank Century terhadap uang yang terdapat dalam Bank Century itu sendiri. Pemilihan kata untuk menyusun headline yang akan digunakan juga dapat mempengaruhi minat khalayak untuk membacanya.

Dalam sub headline terdapat kontradiksi dengan Headline, dimana Kompas menulis "Pansus Bank Century Mencecar", hal itu menunjukkan bahwa pernyataan Boediono bahwa Century Dirampok tidak sepenuhnya benar, oleh sebab itu pansus terus memintai keterangan 
dengan mencecar dengan pertanyaan-pertanyaan kepada Boediono. Dalam sub headline ini terlihat kata "mencecar" yang berarti kegiatan yang terus menerus atau dapat berarti desakkan yang ditujukan kepada Boediono. Pemilihan kata mencecar dapat menunjukkan bagaimana pansus century serius untuk mencari tahu kebenaran dari kasus Bailout ini. Sebagai seorang yang terus menerus ditekan dengan pertanyaanpertanyaan pedas dan mendalam, Boediono diharapkan dapat menjawab semua pertanyaan dengan sebenar-benarnya, tanpa adanya kebohongan maupun pelimpahan tanggung jawab, dengan demikian kasus ini dapat fakta yang akan membuat kasus ini cepat diselesaikan.

Dalam headlinedansubheadline tersebutdapat dilihat bagaimana dalam pemberitaannya Kompas memiliki kecenderungan untuk terus mendesak pemerintah agar dapat meneyelesaikan kasus ini dengan segera berdasarkan fakta-fakta yang telah didapatkan baik melalui Boediono sendiri yang dilakukan oleh pansus maupun dari tokohtokoh lainnya yang dinilai terlibat didalamnya.

Pada berita yang kedua, dalam headline "Wapres Ingatkan Cara yang Elegan" terlihat Kompas membingkai pernyataan Boediono dengan positif, hal tersebut dapat dilihat dari penggunaan kata "Elegan" yang memiliki makna anggun dan sesuai dengan kaidah dan norma-norma yang berlaku dalam hal ini penyelesaian kasus Bailout Bank Century.

Kompas juga menggunakan beberapa kata yang digunakan untuk memperhalus makna. Diantaranya Kompas menggunakan kata "cara yang tidak elok". Kata tersebut merupakan personifikasi dari cara yang kurang baik dan bermakna positif, yang menunjuk kepada setiap aparatur negara dalam penyelesaian kasus Bank Century, kalimat tersebut juga turut memberi penguatan kepada kata elegan yang terdapat dalam kalimat sebelumnya. Kompas juga menggunakan kata "siap lahir batin" untuk menggambarkan bagaimana kesiapan Mahkamah Konstitusi (MK) dalam menyelesaikan permasalah permakzulan yang menyeret Boediono didalamnya. Istilah siap lahir batin digunakan untuk memperdalam makna tentang kesiapan MK itu sendiri. Kompas menggunakan kata "semata-mata". Kata tersebut merupakan kata pengulangan yang termaksud ke dalam jenis personifikasi, penggunaan kata tersebut untuk menggambarkan betapa Boediono tidak takut sama sekali jika jabatannya hilang, karena ia bekerja hanya untuk bangsa dan negara. Dalam berita ini sangat jelas terlihat bagaimana sosok Boediono di bingkai dalam keseluruhan berita Kompas, terlihat dari pemilihan kata-kata yang memiliki makna halus yang mengarah kepada hal yang positif.

Berita selanjutnya dengan headline "Hak Angket Bank Century, Boediono : Ini Baru pandangan Politik" terlihat, Kompas mengangkat tentang pelaksanaan Hak Angket Bank Century, dengan penambahan Sub Headline yang menerangkan tentang tanggapan Boediono terhadap kelanjutan penyelesaian kasus Bank Century yang menganggap hal tersebut baru merupakan pandangan politik. Kompas berusaha meyakini pembaca dengan penulisan sub headline yang tegas dengan mengutip langsung ungkapan tersebut. Dari kutipan langsung tersebut khalayak dibawa untuk menilai bahwa dalam kesimpulan dalam hak angket bukan keputusan final dan memiliki dasar hukum yang kuat, melainkan hanya pandangan politik.

Dalam berita selanjutnya dengan headline "Boediono : Ini Resiko Hidup", Kompas dengan gamblang menjelaskan bagaimana Boediono menganggap apa yang dialaminya merupakan resiko hidup yang harus dijalani sebagai bagian dalam kehidupan dan dari apa yang diungkapkannya merupakan wujud dari ketegaran seorang yang terus menerus mendapat tekanan yang disebabkan oleh keputusan yang pernah diambilnya. Dengan penambahan sub headline pansus Century masih alot membahas kesimpulan, menunjukkan bahwa Kompas menggiring khalayak untuk ikut lebih mengarah ke pernyataan Boediono dibandingkan dengan belum ditemukkannya kesimpulan yang dilakukan oleh Pansus Century. 
Dalam berita selanjutnya Kompas mengangangkat headline "Hak Angket Century, Wapres Boediono Biasa-Biasa Saja" dari headline saja dapat dilihat bagaimana Kompas membingkai beritanya, Kompas mengangap Hak Angket Century merupakan hal yang tidak terlalu berpengaruh terhadap sikap Boediono atau dengan kata lain kasus tersebut kurang mendapatkan perhatian olehnya, maka tidak heran kutipan langsung dari pernyataan Boediono terkait pelaksanaan Hak Angket Century pada berita ini menjadi headline. Penggunaan kata "biasa-biasa saja" oleh Kompas digunakkan untuk mempengaruhi khalayak agar ikut melihat bagaimana Kasus Bailout ini dicuekin oleh Boediono karena dirinya terlihat tidak terlalu memikirkan hasil dari Hak Angket Century sebagai suatu keputusan yang penting dan langsung menyelesaikan permasalahan tersebut padahal Boediono terus didesak dan dalam tekanan terhadap persoalan Century ini. Bisa diartikan bahwa Boediono menganggap ini sebagai suatu hal yang tidak usah dipusingkan oleh sebeb itu masyarakat diharapkannya tidak perlu terlalu mendramatisir dan ikut mengambil pusing mengenai permasalahan ini

Pada lead dan latar berita tersebut Kompas juga menggunakan kata "mengamati" dan "memantau" yang artinya melihat dan memeperhatikan, dimana kedua kata tersebut merupakan kata khusus dari kata umum melihat. Penggunaan kedua kata tersebut oleh Kompas untuk memberi penekanan makna yang lebih halus namun menarik sehingga kandungan maknanya tidak datar. Dimana mengamati dan melihat ditujukan kepada sikap Boediono dalam melihat pelaksanaan Hak Angket Century.

Dalam berita terakhir dengan headline "Hindari Intervensi Politik" Kompas ingin menekankan mengenai pelaksanaan kelanjutan keputusan terkait Bank Century untuk dihindari adanya campur tangan politik didalam penyelesaiannya untuk itu dalam penulisannya Kompas menggunakan kata "Intervensi" yang cukup banyak dipakai dan digunakan di ranah politik. Kemudian di sub headline yang mengungkapkan "Boediono Tegaskan Pantang Mundur" Kompas kembali membangun citra positif seorang Boediono dalam beritanya, dengan pemilihan kata "tegaskan pantang mundur" dapat menggambarkan bagaimana sikap seorang Boediono yang tidak pernah menyerah dalam berjuang sekalipun desakkan untuk mundur dari jabatanya sebagai Wakil Presiden yang dilakukan oleh beberapa kalangan semakin besar, dengan dasar kepercayaan yang diberikan oleh Presiden SBY dan suara sebagian besar rakyat Indonesia yang telah memilihnya dalam pemilu. Penekanan yang positif dalam hal pemilihan kata dari headline dan sub headline tersebut semakin menjelaskan bingkai kompas terhadap berita ini.

Pemilihan narasumber dapat menunjukkan frame dari Kompas, dalam pemilihan narasumber dalam setiap penulisannya, Kompas berusaha untuk menghadirkan keseimbangan atau cover both side dari pihak yang mendukung ataupun yang menolak adanya pemberian dana talangan tersebut. Dalam berita pertama dengan headline "Boediono : Century Dirampok" Dalam berita ini yang berisikan kesaksian Boediono di depan Pansus Century, Kompas banyak menggunakan pernyataan Boediono yang memberikan kesaksian, namun hal tersebut diimbangi Kompas dengan mencantumkan pernyataan dari narasumber yang berasal dari partaipartai yang dikenal kritis terhadap pemerintah diantaranya , Anggota Pansus dari Partai Hati Nurani Rakyat (Hanura) Akbar Faizal, Anggota Pansus dari Partai Gerakan Indonesia Raya (Gerindra) Ahmad Muzani, Anggota Pansus dari Fraksi Partai Demokrasi Indonesia Perjuangan (PDIP) Maruarar Sirait, Anggota Fraksi Partai Demokrat Achsanul Qosasi, Wakil Ketua Pansus dari PDIP Gayus Lumbuun. Dalam berita kedua dengan headline "Wapres Ingatkan Cara Yang Elegan" Kompas menggunakan narasumber seperti Kamrussamad selaku Ketua I Bidang Organisasi Badan 
Pengurus Pusat Himpunan Pengusaha Muda Indonesia (HIPMI), Yopie Hidayat sebagai Juru Bicara Wapres, Menteri Hukum dan HAM Patrialis Akbar, Wakil Ketua DPR Pramono Anung, Ketua Fraksi Partai Demokrat Anas Urbaningrum, Ketua Mahkamah Konstitusi (MK) Mahfud MD, Ketua Mahkamah Agung (MA) Harifin A Tumpa, Ketua Umum PBNU Hazyim Muzadi. Sangat terlihat sikap netral dari Kompas, bagaimana narasumber dapat berasal dari organinasi yang diketuai oleh Boediono yakni HIPMI kemudian dari Menteri juga ada, Partai Oposisi, Mahkamah Konstitusi, Mahkamah Agung, bahkan dari tokoh agama pun ada.

Dalam berita ke tiga dengan headline "Boediono: Ini Baru Pandangan Politik" Kompas menggunakan narasumber antara lain dari Juru Bicara dan Staf Khusus Wapres Bidang Media Massa Yopie Hidayat, Menteri Keuangan Sri Mulyani, Direktur Perencanaan Strategis dan Hubungan Masyarakat Bank Indonesia (BI) Dyah NK Makhijani, Gubernur DIY Sultan Hamengku Buwono X. Terdapat 3 narasumber yang mendukung kebenaran terhadap kebijakan Bailout Bank Century, yakni Juru Bicara Wapres, Menteri Keuangan dan Direktur Perencanaan BI, namun Kompas menggunakan tokoh lain untuk mengimbangi pemberitaan tersebut, yakni sosok Sri Sultan Hamengku Buwono X.

Beritaselanjutnyadenganheadline "Boediono : Ini Resiko Hidup" Kompas menggunakan narasumber Wakil Presiden Boediono, Presiden Susilo Bambang Yudhoyono, Menteri Hukum dan HAM Patrialis Akbar, Staff Khusus Presiden Bidang Hukum dan HAM dan Pemberantasan Korupsi dan Nepotisme Denny Indrayana, Pengamat Sosial William Chang, Pengamat Ilmu Politik Universitas Indonesia Boni Hargens, Ketua MPR Taufiq Kiemas, Ketua Mahkamah Agung Harifin Tumpa, Anggota Tim Pansus dari PDIP Hendrawan Supratikno. Kesemuanya berasal dari lembaga-lembaga yang berbeda, ada yang berasal dari Menteri, Staf Khusus Presiden, Pengamat Sosial, Ketua MPR, MA, MK dan anggota Pansus, bahkan Presiden SBY. Hal tersebut cukup menjelaskan bagaimana Kompas memilih narasumber tidak berasal dari satu instansi saja, melainkan daribanyak Instansi, disini cover both side dari Kompas pun dapat dilihat.

Dalam berita dengan headline "Hak Angket, Wapres Boediono Biasa-Biasa Saja" narasumber yang digunakan Kompas diantaranya Juru Bicara Wapres Yopie Hidayat, Juru Bicara Kepresidenan JulianAPasha, Ketua Mahkamah Konstitusi (MK) Mahfud MD, Ahli Pidana Universitas Gadjah Mada Eddy OS Hiariej, dan Menteri Keuangan Sri Mulyani. Dalam berita tersebut kembali dapat dilihat Kompas kembali menggunakan narasumber yang berasal dari dunia pendidikan yang Non Politik, yakni Ahli Pidana UGM untuk membahas tentang permasalaha permakzulan, selebihnya merupakan mereka yang terkait tentang penyelesaian kasus Bank Century seperti Sri Mulyani, Mahfud MD dan Jubir Wapres. Penggunaan narasumber non politik tersebut cukupmenjelaskanbagaimanaKompasberimbang dalam pemilihan narasumber dari suatu berita.

Dalam berita dengan headline "Hindari Intervensi Politik, Boediono Tegaskan Pantang Mundur" narasumber yang dipilih Kompas diantaranya Ketua Umum Partai Golkar Aburizal Bakrie, Wakil Presiden RI Boediono, Ketua Dewan Pimpinan Pusat (DPP) Partai Demokrat Anas Urbainingrum, Ketua DPP Partai Golkar Priyo Budi Santoso, Ketua Umum Partai Amanat Nasional (PAN) Hatta Rajasa, Anggota PDIP Budiman Sudjatmiko. Selain Boediono, Penggunaan narasumber dari berbagai partai politik yang berkuasa maupun yang oposisi yang dilakukan oleh Kompas semakin menunjukkan keberimbangan pemberitaan dan berusaha menyajikan berita secara cover both side, jadi tidak hanya dari pihak Partai Demokrat saja yang diketahui sangat mendukung Boediono terhadap keputusannnya memberi dana talangan Bank Century, tetapi beberapa partai yang berkoalisi dengan Demokrat bahkan PDIP yang dikenal sangat menentang kebijakan Bailout tersebut. 
Dalam setiap penyajian berita, keberadaan narasumber mutlak hukumnya. Tanpa adanya narasumber suatu informasi yang diperoleh tak layak untuk dimuat dan dilaporkan kepada khalayak. Kemampuan seorang jurnalis dalam menggali suatu fakta dari berbagai sumber akan membuat informasi yang disajikan memiliki nilai berita yang tinggi, sehingga informasi tersebut layak untuk diketahui dan dikonsumsi oleh masyarakat luas.

Dalam menulis berita, Kompas selalu memaksimalkan kelengkapan unsur $5 \mathrm{~W}$ dan $1 \mathrm{H}$, atau dengan kata lain sudah baik dan lengkap untuk suatu penulisan berita straight news. Hal tersebut sangat baik karena dengan mengabaikan kelengkapan unsur $5 \mathrm{~W}$ dan $1 \mathrm{H}$ dalam suatu berita akan dapat membuat bingung khalayak dalam memahami isi berita. Formula $5 \mathrm{~W}$ dan $1 \mathrm{H}$ adalah semacam "rumus kimia" untuk para wartawan agar berita yang disampaikannya benar-benar mengandung semua elemen yang dibutuhkan oleh pembacanya, dan dapat dicek kebenarannya oleh pembaca sendiri.

Untuk frame Kompas, dalam berita pertama dengan headline Boediono : Century Dirampok, Pansus Bank Century Mencecar, Kompas paling tidak memiliki empat frame didalamnya. Frame yang pertama adalah penyebab Bank Century menjadi bank gagal merupakan akibat dari adanya perampokkan yang dilakukan oleh Pemilik Bank Century itu sendiri disamping bersamaan terjadinya krisis global. Frame yang kedua adalah orang yang dianggap bertanggung jawab kepada penentuan status dari Bank Century dan pemberian dana talangan (Bailout) adalah Boediono sebagai Gubernur Bank Indonesia serta Sri Mulyani Indrawati sebagai Ketua Komite Stabilitas Sistem Keuangan. Frame yang ketiga adalah belum ada bukti yang jelas mengenai dana yang dipakai untuk Bailout Bank Century yang melalui Lembaga Penjamin Simpanan (LPS) adalah uang negara. Frame yang ke empat adalah Boediono dalam memberikan keterangan kepada panitia pansus banyak yang tidak jelas dan kabur
Untuk berita yang kedua ini merupakan kelanjutan dari berita sebelumnya dimana hasil dari kesaksian Boediono di depan rapat Pansus Century yang terus menerus mencecarnya ditanggapi langsung oleh Boediono. Dengan headline Wapres Ingatkan Cara yang Elegan, setidaknya Kompas menempatkan dua frame utama didalamnya. Frame yang pertama dalam pengusutan kasus Bailout Bank Century harus ditempuh dengan cara yang demokratis dan elegan dan sesuai dengan aturan yang ada. Frame kedua adalah perkara permakzulan mulai muncul terhadap pemerintahan SBY-Boediono.

Pada berita ke tiga dengan headline Boediono : Itu Baru Pandangan Politik, Kompas meletakkan dua frame didalamnya. Frame pertama adalah hasil keputusan dalam Pansus Century dari para fraksi di DPR baru merupakan pandangan politik dan bukan merupakan pandangan akhir yang menentukkan kebenaran atau kesalahan. Frame kedua adalah kebijakkan yang di ambil oleh Ketua KKSK maupun Gubernur Bank Indonesia pada saat itu bukanlah tindakkan kriminal perbankan

Dalam berita ke empat dengan headline Boediono : Ini Resiko Hidup, setidaknya terdapat tiga frame Kompas. Frame yang pertama kasus Century merupakan resiko hidup yang harus dilalui oleh seorang Boediono dalam kehidupannya. Frame yang kedua SBY ikut terseret dalam isu Permakzulan terkait kasus Bank Century. Frame ketiga adalah Pansus belum menemukan formula yang pas untuk diserahkan kepada pimpinan pansus terkait kesimpulan dan rekomendasi.

Pada berita ke lima kali ini memiliki korelasi dengan berita ke empat diatas, dimana Kompas mengangkat pemberitaan mengenai sikap seorang Boediono dalam menyikapi pelaksanaan penyelesaian kasus Bank Century dan tekanan yang terus datang terhadapnya, dan Kompas pun dalam membingkai kedua berita ini terdapat frame yang memiliki kecenderungan yang sama. Dengan headline Hak Angket : Wapres Boediono Biasa Saja, setidaknya dalam berita kelima ini Kompas menuangkan tiga frame 
didalamnya. Frame yang pertama adalah dalam pelaksanaan pemungutan suara atau Voting dalam Rapat Paripurna DPR yang membahas kasus Bank Centuy seorang Boediono bersikap biasa saja. Frame kedua adalah kelanjutan dari hasil Voting Rapat Paripurna tidak dapat dibawa langsung ke meja Mahkamah Konstitusi (MK) melainkan harus ada proses selanjutnya di DPR. Frame yang ketiga adalah Mentri Keuangan Sri Mulyani Indrawati mempertanyakan sikap para fraksi di DPR dan meminta penjelasan jika memang apa yang telah dilakukannya untuk menyelamatkan century adalah kesalahan

Berita ke enam dengan headline Hindari Intervensi Politik, Boediono Tegaskan Pantang Mundur, setidaknya terdapat tiga frame Kompas. Frame yang pertama adalah kelanjutan kasus Bank Century yang telah memasuki ranah hukum diharapkan tidak ada Intervensi Politik didalamnya agar pelaksanaannya proses hukum tersebut berjalan baik. Frame yang kedua adalah Boediono yang tidak akan mundur dari jabatannya sebagai Wakil Presiden sekalipun desakan untuk mundur dari beberapa kelompok semakin kuat, Dirinya hanya akan mundur jika persyaratan konstitusional telah terpenuhi. Frame ketiga adalah keberadaan partai-partai koalisi tidak akan berubah pasca perbedaan pandangan yang terjadi dalam Hak Angket Bank Century di DPR dan adanya isu perombakkan kabinet

Dalam keseluruhan berita tersebut dari frame SKH Kompas yang diambilnya dapat terlihat bagaimana SKH Kompas memiliki kecenderungan mendesak pemerintah untuk dapat menyelesaikan dengan tuntas kasus Century, tanpa adanya intervensi politik didalamnya maupun hal-hal lain yang hanya dapat membuat kasus ini berlarut-larut tanpa ada penyelesaian. Dalam memberitakan sosok Boediono terkait Kasus Bank Century, SKH Kompas memiliki kecenderungan untuk tidak melakukan suatu pemberitaan yang menyerang Boediono maupun melakukan pemberitaan yang membuat seolah-olah Boediono tidak bersalah.
Kecenderungan itu lebih mengarah kepada desakkan penyelesaian kasus Century oleh Pemerintah karena dalam hal ini Boediono merupakan simbol dari pemerintah dimana pada saat keputusan Bailout tersebut diambil jabatan beliau adalah Gubernur Bank Indonesia dan saat ini pun masih menjabat Wakil Presiden RI

Dalam kasus Bank Century ini, selama belum ada putusan final yang berkekuatan hukum tetap, dan Boediono belum ditetapkan statusnya sebagai orang yang bertanggung jawab penuh terhadap pemberian dana talangan (Bailout) maupun tersangka maka sepanjang itu pula Kompas dalam penyajian berita dan tulisantulisannya selalu diwarnai sikap tenggang rasa dan penuh pengertian namun tetap menyajikan fakta yang sesuai dengan kebenarannya. Kompas akan berusaha menjauhi cara-cara kritik dengan menyakiti hati orang, sebaliknya membiarkan orang memperbaiki sendiri. Dalam mengkritik dan menggugat, Kompas berpedoman "Teguh dalam persoalan, lentur dalam cara" (fortiter in re suaviter in modo). Arti visi humanis-transendental sekaligus adalah visi kemanusian yang historis, bukan hanya berarti keterarahan manusia pada Yang Transenden dan keterbukaan akan Tuhan perlu dimengerti dengan keterbukaannya terhadap dunia.

\section{Simpulan}

Hasil penelitian yang telah diuraikan merupakan sebuah analisis terhadap teks berita media yang memberitakan mengenai ledakan tabung gas elpiji. Skripsi ini adalah hasil interpretasi dan penafsiran peneliti sehingga membuka kemungkinan pihak lain memiliki penafsiran atau interpretasi berbeda dari apa yang dilakukan peneliti. Berbagai fakta yang tersaji di dalam berita merupakan hasil konstruksi realitas yang dilakukan media menurut pandangannya mengenai suatu masalah dan ideologi yang mereka anut. Dengan adanya pembingkaian yang dilakukan oleh Surat Kabar Harian Kompas mengenai 
ledakan tabung gas elpiji, dapat diketahui sikap Surat Kabar Harian Kompas pada kasus tersebut.

Analisis framing yang digunakan dalam penelitian ini adalah model framing yang dikembangkan oleh Zhondang Pan dan Gerald M. Kosicki. Dalam analisis framing ditemukan beberapa hal penting yang berhubungan dengan sikap dan pandangan Surat Kabar Harian Kompas dalam berita tentang ledakan tabung gas elpiji.

Frame dari SKH Kompas memiliki kecenderungan mendesak pemerintah untuk dapat menyelesaikan dengan tuntas kasus Century, tanpa adanya intervensi politik didalamnya maupun hal-hal lain yang hanya dapat membuat kasus ini berlarut-larut tanpa ada penyelesaian. Dan dalam memberitakan sosok Boediono terkait Kasus Bank Century, Kompas memiliki kecenderungan untuk tidak melakukan suatu pemberitaan yang menyerang Boediono maupun melakukan pemberitaan yang membuat seolaholah Boediono tidak bersalah. Kecenderungan itu lebih mengarah kepada desakkan penyelesaian kasus Century oleh Pemerintah karena dalam hal ini Boediono merupakan "simbol" wakil dari Pemerintah, dimana pada saat keputusan Bailout tersebut diambil Jabatan beliau adalah Gubernur Bank Indonesia dan saat ini pun masih menjabat Wakil Presiden.

Tetapi selama Kasus Bank Century belum ada putusan final yang berkekuatan hukum tetap, dan Boediono belum ditetapkan statusnya sebagai orang yang bertanggung jawab penuh terhadap pemberian dana talangan (Bailout) atau tersangka, maka sepanjang itu pula SKH Kompas dalam penyajian berita dan tulisantulisannya selalu diwarnai sikap tenggang rasa dan penuh pengertian namun tetap menyajikan fakta yang sesuai dengan kebenarannya. Dalam penekanan serta penonjolan peristiwa tentang pemberitaan sosok Boediono terkait kasus Bailout Bank Century, cara dan teknik yang dilakukan oleh Kompas adalah dengan melakukan pemilihan kata yang akan digunakan dalam menyusun teks berita secara keseluruhan. Hal itu akan membuat berita yang diinformasikan kepada khalayak akan mudah dicerna dan mudah dipahami atau dimengerti sehingga khalayak akan terpengaruh oleh sikap dan pandangan Kompas mengenai suatu masalah.

\section{Daftar Pustaka}

Eriyanto. (2002). Analisis Framing : Konstruksi, Ideologi, dan Politik Media. Yogyakarta: LkiS

Femadhan. (2010). Analisis Framing. Retrieved from http://www.scribd.com/doc/24111727/ Analisis-Framing.

Hamad, Ibnu. (2004). Konstruksi Realitas Politik dalam Media Massa. Jakarta: Granit.

J, Moleong, Lexy. (2005). Metodologi Penelitian Kualitatif, Edisi Revisi (Cetakan 21). Bandung: PT Remaja Rosdakarya.

Kompas, Team Penerbit. (2007). Kompas Menulis Dari Dalam. Jakarta: PT Kompas Media Nusantara.

http://www.kompas.com 